\title{
ANALISIS PESAN DAKWAH DALAM NOVEL LAYLA MAJNUN
}

\author{
Wahyu Khairul Ichsan \\ Prodi KPI STAIN Teungku Dirundeng Meulaboh \\ E-mail:wahyukhairulichsan@gmail.com
}

\begin{abstract}
Abstrak
Layla Majnun adalah sebuah novel yang di karang oleh seorang sufi sekaligus penyair dari Persia yang bernama Nizami Ganjavi, dia mengungkapkan pemikirannya melalui prosa, puisi dan syair-syair yang sangat kental dengan makna spiritual yang mendalam. Banyak versi tentang kisah Layla Majnun namun karya Nizami yang paling tersohor dan Sudah banyak peneliti yang meneliti tentang novel Layla Majnun namun belum ada peneliti yang meneliti pesan dakwah dalam novel tersebut. Penelitian ini bertujuan menganalisis pesan dakwah yang terkandung dalam novel Layla Majnun. Metode yang digunakan dalam penelitian ini adalah penelitian kepustakaan (library research). Teknis analisis data menggunakan metode analisis isi (content analysis). Temuan penelitian ini menunjukkan bahwa dalam novel Layla Majnun mengandung pesan-pesan dakwah, yaitu pesan dakwah akidah, pesan dakwah syariah, pesan dakwah mua'malah dan pesan dakwah akhlak.
\end{abstract}

Kata Kunci: Analisis Pesan Dakwah, Novel, Layla Majnun.

\begin{abstract}
Layla Majnun is a novel written by a Sufi and a poet from Persia named Nizami Ganjavi, he expresses his thoughts through prose, poetry, and poetry which is very thick with deep spiritual meaning. There are many versions of the story of Layla Majnun, but Nizami's work is the most famous and there have been many researchers who have researched the Layla Majnun novel, but no researcher has yet examined the da'wah message in the novel. This study aims to analyze the da'wah messages contained in the Layla Majnun novel. The method used in this research is library research. The data analysis technique uses the content analysis method. The findings of this study indicate that the novel Layla Majnun contains da'wah messages, namely the message of the creed, the message of preaching sharia, the message of preaching mua'malah, and the message of da'wah morals.
\end{abstract}

Keywords: Da'wah Text Analysis, Novel, Layla Majnun.

\section{PENDAHULUAN}

Berdakwah melalui sastra membutuhkan setidaknya idealisme yang jelas serta kekayaan bahasa, agar karya kita mampu menggerakan seseorang. Novel 
sangat berpotensi sebagai media dakwah untuk mengenalkan keindahan Islam yang dikemas melalui bahasa yang khas, halus, indah, komunikatif, dengan menggunakan metode dakwah yang khas dari seorang pengarang atau penulisnya untuk disampaikan kepada para pembaca dan pecinta novel.

Karya tulisnya bukan bermaksud untuk menggurui para pembaca tetapi hanya sekedar memberi tahu dan memberi gambaran tentang ajaran islam dan perjuangan hidup secara sederhana tapi amat sangat mengena di hati mereka yang membacanya. Salah satu contohnya adalah novel "Layla Majnun" karya Nizami Ganjavi yang menjadikan karya tulisanya menjadi pelajaran yang patut dicontoh oleh pembacanya dan pendakwah. Sesuai fungsi komunikasi massa dalam novel terlihat bagaimana Nizami Ganjavi memberi informasi kepada pembaca tentang keadaan daerah Persia pada zaman dulu dan mengembangkan sastra arab melalui syair-syairnya khususnya dalam novel Layla Majnun.

Layla Majnun merupakan representasi dari dunia Timur yakni Persia yang sekarang dikenal dengan Negara Iran. Syair Layla Majnun ditulis Syaikh Nizami pada tahun 1188 M. Syair ini ditulis berdasarkan cerita rakyat Arab-Persia yang telah ada sejak lima ratus tahun sebelumnya. Dalam masyarakat Arab-Persia ketika itu, Majnun acapkali dihubungkan dengan tokoh yang benar-benar pernah ada, yaitu Qays bin al-Mulawwah, yang hidup pada paruh kedua abad ke-7 di padang pasir Najd di semenanjung Arab. Pada masa Nizami, ada banyak sekali variasi tema mengenai Majnun yang tersebar di seluruh daerah itu, tetapi yang terkenal tetap saja karyanya Syekh Hakim An-Nizami yang biasa disebut Nizami, dikenal sang penutur kisah cinta yang mendunia dengan syair syair cintanya yang menghipnotis setiap pendengar dan pembacanya.

Dakwah yang umumnya disampaikan dalam bentuk lisan dan tulisan pada hari ini lebih sering tampil dalam bentuk nada ancaman "Paksaan" dibandingkan tampil dalam bentuk ajakan berlandaskan kepedulian dan kasih sayang ini terlihat dari beberapa pendakwah yang mudah mengkafirkan, menbid'ahkan dan tidak mudah mendapatkan masukan dari pihak lain.

Penulis melihat dakwah seperti ini telah bergeser dari nilai utama hakikat sebagaimana dalam Al Quran surah An-Nahl ayat 125 Allah SWT berfirman yang artinya "Serulah (manusia) kepada jalan tuhanmu dengan hikmah dan pelajaran 
yang baik dan bantahlah mereka dengan cara yang baik, sesungguhnya Tuhanmu lebih mengetahui siapa yang tersesat dari jalan-Nya dan dialah yang lebih mengetahui orang-orang yang mendapat petunjuk". Disini sangat jelas Allah mengatakan bahwa dalam berdakwah yang utama dengan hikmah. Hikmah dapat dipahami sebagai kebijaksanaan yakni mampu menyesuaikan atau mengharmonikan materi dakwah dengan mad'unya.

Dari kajian akademis, sebetulnya telah banyak penelitian yang dilakukan untuk mengkaji Novel Layla Majnun Karya Nizhami Ganjavi. Baik dari segi bahasa, sejarah, tokoh maupun sastra, namun dari penelitian-penelitian tersebut belum ada yang mengkaji secara khusus tentang pesan Dakwah yang terkandung dalam novel Layla Majnun karya nizhami.

Diantaranya tulisan dari Desta Leila Kartika dari Univerisitas Negeri Semarang, dari hasil penelitianya ia mengatakan bahwa ada hubungan intertekstual antara Novel Layla Majnun karya Nizami Ganjavi dengan novel Romeo and Juliet karya William Shakespear. novel Layla Majnun dan Romeo and Juliet memiliki pengaruh dalam penciptaanya, Layla Majnun merupakan hipogram dari kelahiran Romeo and Juliet.

Hal ini lah yang melatar belakangi penulis untuk melakukan penelitian lebih jauh tentang pesan pesan dakwah yang terkandung dalam novel Layla Majnun karya Nizhami, berdasar amatan dan pemahaman awal penulis dari karya tersebut, menunjukan bahwa Novel Layla Majnun adalah karya yang sangat popular yang mengandung simbol cinta ketuhanan dan cinta yang ideal yang seharusnya ada pada setiap manusia.

\section{LANDASAN TEORI}

\section{A. Analisis Isi}

Analisis isi adalah penelitian yang bersifat pembahasan mendalam terhadap isi suatu informasi tertulis atau tercetak dalam media massa. Pelopor analisis isi adalah Harold D Laswell, yang mempelopori teknik symbol coding, yaitu mencatat lambang atau pesan secara sistematis untuk kemudian diberi interpretasi. ${ }^{1}$

\footnotetext{
${ }^{1}$ Bambang Setiawan, Materi Pokok Metode Penelitian Komunikasi, h. 7.9
} 
Abuddin Menurut Klaus Krippendorff, analisis isi adalah suatu teknik penelitian untuk membuat inferensi-inferensi yang dapat ditiru (replicable) dan sahih data dengan memperhatikan konteksnya. Sebagai suatu teknik penelitian, analisis isi mencakup prosedur-prosedur khusus untuk pemrosesan data ilmiah. Sebagaimana semua teknik penelitian, iabertujuan memberikan pengetahuan, membuka wawasan baru, menyajikan "fakta" dan panduan praktis pelaksanaannya. Ia adalah sebuah alat. ${ }^{2}$

Metode analisis isi sangat tepat digunakan dalam bidang ilmu komunikasi karena yang menjadi objek dalam penelitian ini adalah isi pesan yang disampaikan oleh suatu media komunikasi. Prosedur kerja metode ini hampir sama dengan metode survei, yang membedakan hanyalah objek penelitiannya. Pada metode survei yang menjadi objek penelitiannya adalah individu atau orang, sedangkan pada metode analisis isi, yang menjadi objek analisisnya adalah isi pesan. ${ }^{3}$

Menurut Holsti, metode analisis isi adalah suatu teknik untuk mengambil kesimpulan dengan mengidentifikasi berbagai karakteristik khusus suatu pesan secara objektik, sistematis, dan generalis. Adapun tahapan-tahapan content analysis yaitu seleksi teks, menentukan unit analisis, mengembangkan kategori kategori isi, menandai unit-unit, dan analisis. ${ }^{4}$

Prosedur analisis isi adalah prosedur bertahap dan sistematis yang digunakan untuk menjawab pertanyaan pertanyaan penelitian.

Adapun langkah-langkah yang digunakan dalam analisis isi adalah:

a) Seleksi Data

Dalam analisis isi, keseluruhan teks dibuat kesimpulan-kesimpulan secara umum, kemudian dilakukan pemilihan terhadap teks yang ada hubungannya secara langsung dengan tema atau judul.

b) Menentukan Unit Analisis

Setelah dilakukan analisis, maka beberapa pesan yang ada di keseluruhan teks di catat. Unit pencatatan (Recording unit) yaitu mengenai bagian isi

2 Klaus Krippendorff, Analisis Isi Pengantar Teori dan Metodologi, (Jakarta: Raja Grafindo Persada, 1993), cet. Ke-2, h. 15

${ }^{3}$ Irawan Soehartono, Metode Penelitian Sosial, (Bandung: Remaja Rosdakarya, 2004), cet. Ke-6, hal. 72

${ }^{4}$ Eriyanto. Analisis isi (prenamedia group: Jakarta) hal 32. 
apa yang akan di catat dan di analisis. Setelah menyeleksi cerita yang terdapat dalam Novel Layla Majnun karya Nizami Ganjavi. Peneliti mengambil beberapa isi dialog yang terdapat pada Novel Layla Majnun ke beberapa kategori yang mengandung pesan dakwah, bukan untuk menjawab apa yang dituliskan namun bagaimana disampaikan dalam novel.

c) Mengembangkan Kategori-Kategori Isi

Kategorisasi-kategorisasi yang sudah dibuat dikembangkan menjadi bagian-bagian yang selanjutnya diklasifikasikan sehingga satu sama lain bisa sesuai dan seimbang.

d) Analisis Data

Setelah menjadi beberapa kategori nominal itu mengisyaratkan sebagai data kualitatif. Bentuk bentuk dari beberapa kategori menjadi petunjuk terhadap apa yang dikomunikasikan. Adapun pengetahuan tentang banyaknya bagian-bagian (unit) dari setiap kategori menjadi petunjuk dalam menentukan berapa frekunsi (banyaknya) pesan pesan itu disebutkan dan dikomunikasikan. ${ }^{5}$

\section{B. Novel}

\section{Pengertian Novel}

Novel berasal dari bahasa Italia, yaitu novella (yang dalam bahasa jerman: Novelle). Secara harfiah novella berarti sebuah barang baru yang kecil kemudian, diartikan sebagai cerita pendek dalam bentuk prosa. Dewasa ini istilah novella dan novella mengandung pengertian yang sama dengan istilah Indonesia novelette (Inggris: noveltte), yang berarti sebuah karya prosa fiksi yang panjangnya cukupan, tidak terlalu panjang, namun juga tidak terlalu pendek.

Novel bersifat naratif, artinya lebih bersifat "bercerita" dari pada “memperagakan". Novel bisa membuat penggambaran-penggambaran yang sangat dramatis, nyaris tampak seperti keadaan sesungguhnya melalui teknik cerita atau narasi tertentu. Jadi, dalam novel pembaca melihat semua yang disuguhkan oleh pengarang. Novel merupakan sebuah karya fiksi, yaitu cerita

${ }^{5}$ Siti fatmah, Etika persahabatan remaja (Analisi Isi Dalam Novel Teri Liye), (Semarang 
yang tidak nyata adanya, hanya rekaan semata hasil karangan penulis. Novel adalah gambaran dari kehidupan dan perilaku yang nyata dari zaman pada saat novel itu ditulis". Sebuah novel akan menghadirkan perkembangan satu karakter, situasi sosial yang rumit yang melibatkan banyak pihak yang terjadi beberapa tahun silam secara mendetail yang di ceritanya memiliki keterkaitan antara pembabakan satu dengan yang lainnya sehingga mampu memberikan kesan yang mendalam terhadap pembaca.

2. Sejarah Novel

Sastra modern Indonesia terus berkembang seiring dengan perjalanan waktu dan dinamika kehidupan masyarakatnya. Para ahli menggolongkannya ke dalam berbagai angkatan, dari tahun "e20-an hingga sekarang. Perkembangan novel mulai dari angkatan 2000 cenderung menerbitkan karya-karya yang berani dan vulgar. Seiring berjalannya waktu, muncul pula fiksi-fiksi Islami.

Karya fiksi Islami kemudian didefinisikan sebagai karya sastra berbentuk fiksi yang ditulis dengan pendekatan Islami, baik dalam bentuk tema maupun penggambaran karya. Kehadiran karya Islam tidak spontan. Sejak akhir tahun 1990-an, dunia sastra sebenarnya sudah diwarnai oleh kehadiran fiksi Islam. Tradisi penulisan fiksi Islami terus berkembang hingga tahun 2000-an. Banyak penulis fiksi Islami ternama diantaranya Asma Nadia, Pipiet Senja, Maemun Affany, dan Habiburrahman El Syirazi.

3. Jenis-Jenis Novel

Novel digolongkan berdasarkan jenisnya, yaitu:

a) Novellet Romantis adalah novellet yang menceritakan kisah-kisah percintaan.

b) Novellet misteri adalah novellet yang menceritakan kisah-kisah misteri dan menimbulkan rasa penasaran pembaca.

c) Novellet komedi adalah novellet yang memuat unsur-unsur humor sehingga membuat para pembaca terhibur.

d) Novellet horor adalah novellet yang memberikan efek menegangkan bagi pembaca.

e) Novellet inspiratif adalah novellet yang berisi kisah-kisah insipratif. 
Dilihat dari kelima macam genre novellet diatas, Novel Layla Majnun karya Nizami Ganjavi termasuk kedalam jenis novel Romantis. Sesuai judul novellet dan jalan ceritanya, novel ini membahas mengenai kecintaan seseorang terhadap kekasihnya.

\section{Biografi Nizami Ganjavi}

Namanya adalah Jamaludin Ilyas Bin Yusuf Bin Zaki yang lebih dikenal denga nama penanya yaitu Nizami Ganjavi. (1141-1209 adalah seorang pujangga sufi yang dianggap sebagai penulis yang membawa gaya tutur realistis kedalam kisah epik sastra Persia. Nizami lahir di Ganja salah satu kota besar di Azerbaijan, bagian kesultan Seljuk, ia menghabiskan seluruh masa hidupnya disana. Karya karya nya tidak hanya dipengaruhi oleh sastra arab dan Persia, baik tradisi oral atau tulisan, melainkan juga oleh matematika, astrologo, kimia, farmasi, ilmu tafsir, teori dan hukum islam, sejarah, filsafat dan mitisisme, musik dan seni visual, jejak jejak Nizami sangat terasa dalam kesastraan islam. Karya tulisnya mempengaruhi perkembangan sastra Persia, Arab, Turki, Kurdi, Urdu dan Nusantara.

Layla Majnun adalah karyanya yang paling tersohor. Karyanya yang lain adalah makhzan Al-asrar yang bearti gudang rahasisa, Haft Peykar (tujuh bidadari), dan Eskandarnameh (Kitab iskandar).

\section{Novel Layla Majnun}

Layla Majnun sesungguhnya adalah kisah cinta klasik yang dikisahkan dari mulut ke mulut di negeri Arab sejak Dinasti Umayyah berkuasa pada tahun (661-750 Masehi). Kisah Layla Majnun diyakini oleh banyak orang roman ini didasarkan pada kisah nyata bernama Qays Ibnu Al-Mulawwah, penguasa Bani Amir di Arabia.

Ada banyak versi cerita pada masa itu. Dalam salah satu versi, Qays menghabiskan masa remaja nya bersama Layla di perkampungan tenda mereka. Dalam versi lain, Qays hanya memandang Layla dan langsung jatuh cinta kepadanya dengan cinta membuatnya pikun kepada dunia. Betapapun, ada sebuah persamaan dalam masing masing versi yaitu Qays menjadi gila karena cintanya kepada Layla, karena alasan itulah dia disebut Majnun yang bearti gila. Melalui 
kisah itulah kemudia syair syair Arab, yang berbicara tentang romantika cinta majnun dan kesetiaan Layla yang menggetarkan digubah.

Dari tradisi lisan kisah tersebut kemudian merasuk ke khazanah sastra Persia dan Nizami Ganjavi menuliskannya pada abad ke-12 dalam bahasa Persia. Dalam versi Nizami ini Qays dan Layla sama sama jatuh cinta ketika keduanya bertemu di sekolah tempat mereka menuntut ilmu bersama, namun mereka terpisah karena ayah Layla tidak menyetujui hubungan mereka. Dalam perjalanan, Layla dinikah kan secara paksa oleh ayahnya dengan lelaki yang bernama Ibnu Salam, namun Ibnu salam tidak pernah bisa menjamah keperawanan Layla yang senantiasa setia kepada Qays hingga akhir hayatnya. Sementara itu, Qays berubah menjadi gila hingga dia lebih terkenal dengan sebuta Majnun. Ia kehilangan unsure kemanusiaan dalam dirinya, berkawan dengan binatang binatang buas dalam rimba, dan jiwanya sepenuhnya lebur kedalam bayang bayang kekasihnya.

Jauh lebih penting dari Nizami adalah pandangannya tentang takdir yang menimpa Layla dan Majnun, yang sangat berbeda dengan pandangan Barat tentang makna tragedy dan penderitaan, mereka mengangap bahwa tidak terpenuhi cintanya mereka didunia adalah ciri khas dari mistisisme yang dihidupi oleh Nizami. Laylanya Nizami menyatakan dengan jelas bahwa didalam cinta, kedekatan yang terlalu dekat sangatlah berbahaya bagi sepasang kekasih. Dengan demikian, penderitaan para pencinta tidak bisa dikatakan sebagai tragis, tidak bisa di interpresentasikan dari sudut pandang moralitas konvensional. Penderitaan pecinta meruntas belenggu sifat kemanusiaan, memampukan mereka untuk bebas dari diri yang terikat dengan dunia fana. Kematian adalah pintu gerbang menuju dunia sejati, kerumah yang dihasrati jiwa para pencari, dan Nizami menyikap hal ini dalam metafora-metafora yang brilian dan dinamis seperti lilin yang membakar dirinya sendiri, kerang yang merana karena mengandung mutiara, batu permata yang merindu ingin terbebas dari batu karang tempatnya tidur selama jutaan tahun seperti Majnun meniadakan "pemakan" dalam dirinya, mengatasi rasa lapar, egoism, dan kepemilikan, serta membubarkan lapak-lapak perasaan didalam tubuhnya.

Jami, pujangga Sufi Persia abad ke-15, yang menulis roman alogeris Yusuf Zulaikha, mengungkapkan, "meskipun hampir semua karya Nizami pada 
permukaan nya tampak sebagai roman, dalam kenyataannya karya-karyanya menampilkan selubung bagi kebenaran-kebenaran hakiki dan pengetahuan ilahi." Goethe, pujangga besar jerman, berujat, "Roh agung yang berbicara tentang perhelatan termanis dari cinta yang terdalam, itulah Nizami”.

Melalui Nizami, kisah tersebut kemudian menyebar kewilayah Turki, Eropa, Afrika, Kaukasus, India, Nusantara, dan mempengaruhi banyak penulis setelahnya, termasuk Jalaludin Rumi, Pujangga Sufi terbesar. Menurut salah satu sumbe, kisah Romeo Juliet yang ditulis oleh William Shakespeare pun di pengaruhi oleh karya ini. Kemasyhuran kisah ini memberikan ilham bagi banyak seniman baik pelukis, pemusik, maupun sineas, dalam menciptakan beragam karya seni yang menggambarkan kisah cinta tak terbalas, namun cinta itu sendiri mentransformasikan pecintanya ke dalam persatuan mistik dengan Sang Kekasihnya. ${ }^{6}$

Beberapa peneliti terdahulu memfokuskan peneliti pada hubungan intertekstual novel Layla Majnun dengan novel Romeo and Juliet,adalah jurnal Desta Leila Kartika dalam kumpulan jurnal sastra Indonesia, ${ }^{7}$ kemudian ada Jurnal Novita Erma dari Program studi Pendidikan Bahasa dan Sastra Indonesia FKIP Untan Pontianak yang meneliti tentang analisis psikologi sastra tokoh utama Novel Layla Majnun karya Syeikh Nizami, berdasarkan penelitiannya menyatakan bahwa emosi positive terbagi menjadi dua, yaitu gembira dan cinta sedangkan emosi negative yaitu takut, marah, sedih, dan cemas atau gelisah. Semua emosi terdapat pada tokoh dalam novel maha cinta Layla Majnun. ${ }^{8}$

\section{METODOLOGI PENELITIAN}

Jenis Penelitian yang merupakan penelitian kualitatif, menurut Bogdan dan Taylor sebagaimana yang dikutip oleh Moleong, mendefinisikan bahwa penelitian kualitatif merupakan prosedur penelitian yang menghasilkan data

6 Nizami Ganjavi, Layla Majnun, penerjermah Ali Noerzaman, (tanggerang selatan: Javanica,2020), hal.217

${ }^{7}$ Desta Leila Kartika, Hubungan intertekstual Cinta Abadi Layla Majnun dengan Romeo and Juliet, Http: Journal.unnes.ac.id/sju/index.php/jsi. diakses pada tanggal 18 oktober 2020

${ }^{8}$ Novita Erma, Analisis Psikologi Sastra Tokoh Utama Novel maha Cinta Layla Majnun karya Syeikh Nizami. Http: media,neliti.com/media/publications.pdf. diakses pada tanggal 18 oktober 2020 
deskriptif berupa kata-kata tertulis atau lisan dari orang orang dan perilaku yang diamati. ${ }^{9}$

Dalam penelitin ini penulis menggunakan pendekatan Analisis isi (content analysis). Content analysis meliputi upaya-upaya klasifikasi lambang-lambang yang dipakai dalam komunikasi menggunakan kriteria dalam klasifikasi dan menggunakan tekhnik analisis tertentu dalam membuat prediksi. ${ }^{10}$ Analisis isi memfokuskan risetnya pada isi komunikasi yang tersurat (tampak atau manifest) karena dalam menganalisis datanya diperlukan suatu analisis isi media dan mampu menghubungkannya dengan konteks sosial/realitas yang terjadi sewaktu pesan dibuat, semua pesan teks, simbol, gambar, dan sebagainya adalah produk sosial dan budaya masyarakat. ${ }^{11}$

Sumber data yang diperoleh adalah dari Data primer yaitu data yang berupa novel Layla Majnun karya langsung dari Nizami Ganjavi, yang menjadi rujukan pertama dalam penulisan skripsi ini, data ini disebut sebagai data utama dan Data sekunder yakni karya yang ditulis orang lain yang mendukung pembahasan serta berbagai karya yang relevan dengan pembahasan pendidikan spiritual.

Objek penelitian ini adalah novel Layla Majnun. Sedangkan, unit analisis penelitiannya adalah potongan syair syair dan isi cerita yang terdapat dalam novel Layal Majnun yang berkaitan dengan rumusan masalah dalam penelitian.

Teknik pengumpulan data yang ditempuh oleh penulis dengan Teknik dokumentasi ini dilakukan dengan mencari data utama yang berasal dari teks yang terdapat pada novel Layla Majnun Karya Nizami Ganjavi dan bahan-bahan lain yang berkaitan dengan judul penelitian.

Teknik analisis data yang digunakan dalam menganalisis pesan Dakwah dalam Novel Layla Majnun menggunakan analisis isi (content analysis). Menurut Holsti, metode analisis isi adalah suatu teknik untuk mengambil kesimpulan dengan mengidentifikasi berbagai karakteristik khusus suatu pesan secara

9 Moleong, Lexy J. 2004. Metode Penelitian Kualitatif. Bandung: PT. Remaja Rosdakarya. Hal.100

${ }^{10}$ Bungin, Burhan. 2015. Metodologi Penelitian Kualitatif. Depok: Rajagrafindo Pustaka, Hal 4

${ }^{11}$ Kriyantono, Rachmat. 2010. Teknik Praktis Riset Komunikasi. Jakarta: Prenada Media Group Hal 249 
objektik, sistematis, dan generalis. ${ }^{12}$ Adapun tahapan-tahapan content analysis yaitu seleksi teks, menentukan unit analisis, mengembangkan kategori kategori isi, menandai unit-unit, dan analisis materi penelitian yaitu yang berkaitan dengan Novel Layla Majnun.

\section{HASIL DAN PEMBAHASAN}

Berdasarkan penelitian yang dilakukan dari analisis isi dan prosedur yang sudah dijelaskan, ditemukan bahwa pesan pesan dakwah tersebut terbagi dalam beberapa kategori yaitu:

\section{Teks Kalimat yang Mengandung Pesan Akidah}

a. Bab 9 halaman 128

Pesan Akidah yang terkandung dalam teks novel Layla Majnun bab 9 halaman 128 terbagi menjadi 2 yang dilihat dari segi kalimat yaitu:

1. Relasi cinta sebagai hubungan yang sempurna antara Tuhan dengan hamba.

Relasi yang harus di bangun antara seorang hamba dengan Tuhannya ialah relasi cinta, artinya relasi pecinta dengan kekasihnya, bukan relasi budak dengan tuan dalam artian formal. Sebagaimana dijelaskan oleh ibnu arabi bahwa jalan satu-satunya menuju tuhan adalah cinta. William Chittik selaku ahli Ibnu Arabi menyebut metode pemahaman Syaikh Akbar (Ibnu Arabi) menyebut metode pemahaman Syaikh Akbar sebagai hermeneutik kasih sayang. ${ }^{13}$

Jika relasi antara seorang hamba dengan tuhannya dalam bentuk relasi budak dan tuan dalam artian formal maka ini akan berakibat munculnya rasa pamrih dalam setiap ibadah yang dilakukan si hamba, Jika seseorang dalam melakukan perintah-perintah agama berlandaskan rasa pamrih maka otomatis akan menimbulkan rasa keterpaksaan dalam setiap tindakan si hamba, artinya si hamba terpaksa untuk melakukan karena jika tidak maka dia nantinya akan di masukkan ke dalam neraka. Lain hal nya jika seseorang membangun relasi dengan tuhan dengan relasi cinta, yakni antara pecinta dengan kekasihnya, maka apa pun perintah yang diberikan oleh tuhan melalui petunjuk Alquran dan Sunah sama sekali tidak menjadi beban dalam

\footnotetext{
${ }^{12}$ Eriyanto. Analisis isi (prenamedia group: Jakarta) hal 32.

${ }^{13}$ Candra Malik, Makrifat Cinta (Jakarta Selatan: Noura Books,2012), hal xxi.
} 
melaksanakan bahkan sebaliknya dia akan senang dan bahagia dengan hal tersebut karena merasa bahwa itulah yang di sukai oleh kekasihnya.

Ini sesuai dengan kalimat majnun, Sebagaimana kalimat Majnun "Bila kau tahu hakikat seorang pecinta, kau akan menyadari bahwa ketunggalan harus meniadakan dirinya, untuk musnah kedalam pelukan kekasihnya". Hal ini serupa dengan ungkapan sebuah syair yang sudah sangat terkenal, yaitu syairnya Rabiah al- Adawiyah:

"Tuhan, jika ibadahku kepada Mu karena takut neraka campakkan saja aku ke dalamnya. Tuhan, jika ibadahku kepada Mu karena harap surga tutplah pintu surga itu untukku. Namun Tuhan, jika aku beribadah kepada Mu semata- mata karena mengharapkan keindahan Mu maka janganlah engkau palingkan wajah Mu dari ku'. ${ }^{14}$

2. Tauhid Hakiki

Yakni meng-esa-kan Allah dengan sebenarnya, yang bermakna meniadakan diri, menghilangkan ego dengan cara melawan hawa nafsu dan menyucika jiwa. Hal ini nampak dalam kalimat "karena satu nama lebih baik daripada dua. Satu nama bisa dipakai untuk berdua”. Meniadakan diri berarti menghadapi semua keinginan hawa nafsu dan mengalahkannya, nafsu amarah dan nafsu kebinatangan haruslah di tundukkan sehingga dapat sampai kepada tauhid yang hakiki tersebut. Jika hawa nafsu sudah ditundukkan maka seseorang akan sampai pada kualitas tauhid hakiki, ditinjau dari cita ajaran tasawuf dunia (hawa nafsu) itu merupakan belenggu yang memperbudak manusia sehingga manusia dituntut untuk melepaskan belenggu tersebut. ${ }^{15}$

Sebagaimana yang di kabarkan dalam sebuah hadis yang berarti: Artinya:...Dan tidaklah hamba-Ku mendekatkan diri kepada-Ku dengan sesuatu ibadah yang lebih Aku cintai dari apa yang telah Aku wajibkan kepadanya. Dan senantiasa seorang hambaKu mendekatkan diri kepadaKu dengan amalan-amalan Sunah hingga Aku mencintainya. Jika Aku mencintainya maka Aku menjadi pendengarannya yang ia gunakan untuk mendengar, penglihatannya yang ia gunakan untuk melihat, dan sebagai tangannya yang ia gunakan untuk berbuat, dan sebagai kakinya yang ia gunakan untuk berjalan. Dan jika ia meminta (sesuatu) kepada-Ku pasti Aku akan

\footnotetext{
${ }^{14}$ M. atiyah khamis, "penyair wanita sufi rabiah” terjemahan. Aliudin mahjudin (Jakarta: pustaka,1993), hal 45

${ }^{15}$ Simuh Tasawuf dan Perkembangannya dalam Islam (Jogjakarta: ircisod,2019). hal 66
} 
memberinya, dan jika ia memohon perlindungan kepada-Ku pasti Aku akan melindunginya." (HR. Al-Bukhari).

b. Bab 6 halaman 95

Dalam bab 6 dengan judul "Majnun Semakin Gila" pada halaman 95 peneliti menemukan satu dialog yang mengandung pesan dakwah akidah, suatu waktu Majnun berkata:

Menyadari bahwa diri ini hanyalah seorang hamba. Dalam proses menjalankan syariat agama dalam kehidupan sehari-hari, seseorang harusnya menyadari dengan sepenuhnya bahwa dirinya adalah seorang hamba, artinya seseorang tidak punya daya dan upaya dalam segala hal selain dari pertolongan Allah SWT. Ini terlihat Dalam kalimat "Aku ini tahananmu, dan kaulah hakimnya. Kutuklah aku! Hukumlah aku sekeras yang kau mau”, menggambarkan sebuah pengakuan dari seorang hamba kepada Tuhan, mengakui bahwa dirinya tak berdaya, dan satu- satunya yang memiliki kekuasaan mutlak adalah tuhan itu sendiri. Mengenai pengakuan kelemahan diri seorang sufi dari Persia Jalaludin Rumi juga menjelaskan "barang siapa mengakui dan memaklumatkan kelemahannya, ia mempercepat diri dalam jalan menuju penyempurnaan! tidak akan bergerak maju menuju sang mahakuasa dia yang menggagap dirinya sempurna " 16 .

Jika seseorang punya kesadaran akan hal ini maka akan berimplikasi positif dalam pelaksanaan syariat agama dalam kesehariannya. seperti tidak akan menyalahkan- nyalahkan ibadah orang lain, tidak menghakimi orang lain, tidak menuduh orang lain sebagai si munafik, si fasik, si murtad, apalagi mengatakan kafir kepada orang lain. Hal ini hanya mungkin terjadi jika seseorang mampu menyadari bahwa dirinya hanyalah sebatas hamba yang diberikan kewajiban untuk beribadah kepada Allah SWT dan bukan untuk menghakimi orang lain. sebagaimana Allah SWT berfirman:

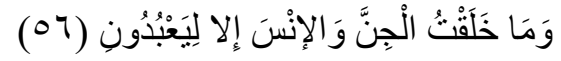

Artinya: Dan aku tidak menciptakan jin dan manusia melainkan supaya mereka mengabdi kepada-Ku. (Az- Zariyat, ayat: 56).

Dalam ayat tersebut jelas terlihat bahwa tujuan penciptaan Jin dan manusia ialah semata- mata untuk menyembah kepada Allah SWT, beribadah berarti mendekatkan diri kepada Allah dengan amalanamalan yang di sukai oleh Allah SWT, seperti kasih sayang, saling

${ }^{16}$ Jalaludin rumi, Matsnawi (Jakarta, penerbit zaman 2019) hal 101 
menolong, menyambung silaturahmi, dan lain sebagainya, dan bukan untuk menghakimi ibadah orang lain, apalagi sampai mengatakan bahwa orang lain itu masuk neraka. Menyatakan orang lain itu celaka atau masuk neraka adalah hak mutlak Allah SWT bukan hak manusia selaku hamba.

c. Bab 2 halaman 35

Pesan Akidah yang terkandung dalam teks novel Layla Majnun pada bab 2 diantaranya adalah:

1. Belajar Mencintai Tuhan

"Majnun termasyhur sebagai seorang pencinta, karena ia menanggung beban cinta seumur hidupnya”. Cinta yang dimaksud di sini adalah cinta ilahiyat (cinta ketuhanan), Majnun melanjutkan bahwa cinta itu seperti tungku api yang membakar jiwa "Cinta adalah tungku api yang membakar jiwa pencinta", ini menunjukkan bahwa jika seseorang menjadi pecinta yang dalam hal ini berarti cinta ketuhanan maka orang tersebut tentu akan memberikan yang terbaik kepada kekasihnya tanpa mengenal pamrih dan lelah disebabkan cinta dalam hatinya terus- menerus menyala memberikan kekuatan yang tak terbatas untuk memberikan yang terbaik. Hal ini juga terdapat dalam syairnya Jalaluddin Rumi:

"karena cinta pahit berubah menjadi manis, Karena cinta tembaga berubah menjadi emas. Karena ampas berubah berubah jadi sari murni, Karena cinta pedih menjadi obat. Karena cinta kematian berubah menjadi kehidupan Karena cinta raja berubah menjadi hamba"17

2. Pecinta senantiasa mengingat kekasih

Majnun juga menyifati cinta sebagai "Cinta adalah wangi bunga dan hembusan angin”. Ketika seseorang sudah mencintai Tuhan maka orang tersebut tentunya selalu mengingat- Nya di mana pun dan kapan pun tanpa batas waktu, mengingat Tuhan tidak hanya sebatas dalam shalat, membaca Alquran, akan tetapi dalam segala keadaannya. "Cinta adalah wangi bunga dan hembusan angin", kata "wangi" dan "hembusan angin" merujuk kepada sesuatu yang tidak terbatas, dan tidak dapat dibatasi. Dalam Alquran dijelaskan bahwa seseorang haruslah senantiasa mengingat Allah dengan sebanyakbanyaknya, Allah berfirman:

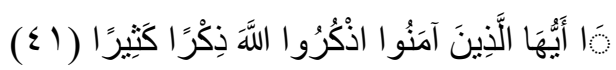

\footnotetext{
${ }^{17}$ Haidar Bagir, belajar Hidup dari rumi. (Jakarta Selatan: Mizan,2015), hal. ix
} 
Artinya: Hai orang-orang yang beriman, berzdikirlah (dengan menyebut nama) Allah, zikir yang sebanyak-banyaknya. (Qs. AlAzhab, ayat: 41).

Mengingat sesuatu tanpa ada batas waktu merupakan sifat dari para pecinta, jika seseorang mencintai tuhan tentunya dia akan sering menyebut dan mengingatnya (zikir) kapan pun dan di mana pun.

\section{Kalimat Pesan dakwah tentang syariah}

Pesan dakwah tentang syariah dalam teks novel Layla Majnun pada bab 6 halaman 95 adalah Senantiasa merasa diri sebagai pendosa terlihat dari kata kata majnun. Majnun berkata: "Kemarin aku berbuat kejahatan dan aku kembali dengan kaki terantai untuk mendapatkan siksaan darimu. Bunuhlah aku, tetapi jangan tolak diriku. Bagaimana aku bisa mengaku tak berdosa dihadapanmu? Kau setia, bahkan ketika kau mencampakan kesetiaan. Aku berdosa, bahkan ketika aku tak bersalah apa apa". Dalam kalimat ini menunjukkan pengakuan yang sedalam- dalamnya dari Majnun, pengakuan bahwa dirinya bersalah dan berdosa, merasa dirinya hina di depan sang Maha Kuasa. Kalimat dari Majnun tersebut mengajarkan kepada kita untuk senantiasa merasa bersalah, berdosa dan hina di depan Tuhan, sehingga kita pun senantiasi memperbaiki diri, sibuk dengan aib sendiri dan tidak sibuk memperhatikan aib orang lain, sebagaimana sebuah hadis menjelaskan yang artinya, "berbahagialah orang yang disibukkan dengan aib sendiri daripada menyibukkan diri dengan aib orang lain" (HR. AdDailami).

Dari kalimat tersebut dapat ditarik kesimpulan bahwa seseorang dalam beribadah mestilah senantiasa melihat kepada kekurangan dirinya sendiri, kelalaiannya sendiri, bukan melihat orang lain. Mengakui diri sebagai pendosa, sebagai orang yang penuh dengan dosa, sehingga tak ada lagi ruang dalam hatinya untuk menilai ibadah orang lain.

\section{Kalimat pesan dakwah tentang Akhlak}

Pesan dakwah akhlak yang terkandung dalam teks novel Layla Majnun pada bab 11 halaman 169 adalah tentang bagaimana seseorang harus memiliki hati yang selamat (qalbun salim), merasa cukup terhadap permberian Allah (qanaah), dan tidak tamak terhadap dunia, ini tergambar dalam kalimat "lapar 
kita adalah perangkap tempat nasib- nasib menjerat kita. Semakin kita tamak, semakin besar bahaya nya. Hanya orang seperti dirimu, yang puas dengan sedikit rumput, yang bisa hidup bebas. Ia adalah seorang raja didunianya”. seseorang yang mampu bersikap seperti demikian, yakni membersihkan hati, tidak tamak terhadap dunia, dan merasa cukup dengan karunia Allah adalah seorang yang menjadi raja di dunia ini.

Sebagaimana firman Allah dalam Qur'an Surta Al-Baqarah ayat 155

"Sesungguhnya kami akan mengujimu dengan suatu cobaan, yaitu ketakutan, kelaparan, kekurangan harta, jiwa dan buah-buahan, berilah kabar gembira kepada orang-orang yang sabar". (Al Baqarah:155) ${ }^{18}$.

\section{Kalimat pesan dakwah tentang mu'amalah}

a. Bab 9 dalam halaman 131

Pesan mu'amalah dari teks Novel Layla Majnun halaman 131 adalah Melihat segalanya dengan kasih sayang. Dalam teks tersebut Majnun ingin mengajarkkan bagaimana kita hidup berdampingan dengan makhluk lain, baik itu manusia, binatang, tumbuhan maupun alam. Khususnya dengan manusia haruslah berkasih sayang tanpa harus mempertanyakan sekat-sekat agama, ras, suku, bangsa, dan negara, apalagi hanya berlainan kelompok. Karena dalam kehidupan kita meniscayakan pluralitas atau kemajemukan namun tujuan dari perbedaanperbedaan itu bukanlah untuk mempersempit kasih sayang atau pilih kasih melainkan untuk saling kasih sayang dan saling menghormati selaku makhluk tuhan, sebagaimana Firman Allah SWT:

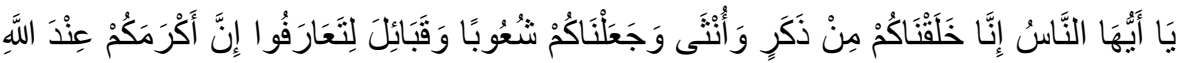

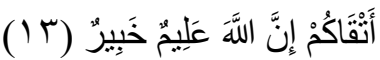

Artinya: Hai manusia, Sesungguhnya Kami menciptakan kamu dari seorang laki-laki dan seorang perempuan dan menjadikan kamu berbangsa - bangsa dan bersuku-suku supaya kamu saling kenal-mengenal. Sesungguhnya orang yang paling mulia diantara kamu disisi Allah ialah orang yang paling taqwa diantara kamu. Sesungguhnya Allah Maha mengetahui lagi Maha Mengenal. (QS. AlHujurat, ayat: 13).

${ }^{18}$ Abul Qasim Abdul Karim Hawazin Al-Qusyairi An Naisaburi. Risalah Qusyairiyah (Pustaka Anami: Jakarta) hal 191 


\section{b. Bab 10 halaman 156}

Pesan dakwah mu'amalah yang terkandung dalam teks Novel Layla Majnun halaman 156 adalah turut Merasakan kesedihan orang lain. Ini terlihat pada Pada awal teks Layla mengatakan "Aku telah mendengar berita tentang kematian ayahmu, dan sangat menyedihkan hatiku. Dalam kesedihan aku memukul wajahku dengan tanganku seolah olah ayahku sendirilah yang mati”. Ini menunjukan bagaimana Layla merasakan apa yang dirasakan Majnun, ditinggal oleh seorang orang tua yang membesarnya. Dalam teks tersebut Layla ingin mengajarkan kepada kita bagaimana cara merasakan apa yang orang lain rasakan, ini bertujuan untuk meggugah dan mengasah nurani kita, dan di sisi lain ini juga mengajarkan tentang rasa syukur kepada Allah, simpati diartikan sebagai keikutsertaan merasakan perasaan (senang, susah, dan sebagainya) orang lain ${ }^{19}$.

\section{KESIMPULAN}

Berdasarkan pembahasan uraian skripsi dengan judul pesan dakwah dalam Novel Layla Majnun karya Nizami Ganjavi, maka dapat disimpulkan bahwa terdapat muatan pesan dakwah dalam karya novel Layla Majnun dan diantara pesan dakwah dalam novel tersebut yang dominan adalah pesan dakwah Akidah. Adapun pesan dakwah yang terkandung dalam novel Layla Majnun karya Nizami Ganjavi adalah:

1. Pesan dakwah tentang akidah

Dalam novel Layla Majnun mengajarkan kita bagaimana membangun hubungan dengan tuhan dengan atas nama cinta artinya relasi pecinta dengan kekasihnya, bukan relasi budak dengan tuan dalam artian formal. Jika relasi antara seorang hamba dengan tuhannya dalam bentuk relasi budak dan tuan dalam artian formal maka ini akan berakibat munculnya rasa pamrih dalam setiap ibadah yang dilakukan si hamba.

2. Pesan dakwah tentang syariah

Dalam Novel Layla Majnun mengajarkan kita untuk Menyadari bahwa diri ini hanyalah seorang hamba, artinya seseorang tidak punya daya dan upaya dalam segala hal selain dari pertolongan Allah SWT.

\footnotetext{
${ }^{19}$ Kamus Besar Bahasa Indonesia, Arti Kata Simpati diakses pada tanggal 30 juni 2020
} 
3. Pesan dakwah tentang akhlak

Pesan akhlak yang terkandung dalam Novel Layla ialah tentang bagaimana seseorang harus memiliki hati yang selamat (qalbun salim), merasa cukup terhadap permberian Allah (qanaah), dan tidak tamak terhadap dunia, seseorang yang mampu bersikap seperti demikian, yakni membersihkan hati, tidak tamak terhadap dunia, dan merasa cukup dengan karunia Allah adalah seorang yang menjadi raja di dunia ini.

4. Pesan dakwah tentang muamalah

Novel Layla Majnun mengajarkan kita untuk Melihat segalanya dengan kasih sayang. Dalam syairnya Majnun ingin mengajarkkan bagaimana kita hidup berdampingan dengan makhluk lain, baik itu manusia, binatang, tumbuhan maupun alam. Khususnya dengan manusia haruslah berkasih sayang tanpa harus mempertanyakan sekat-sekat agama, ras, suku, bangsa, dan negara, apalagi hanya berlainan kelompok.

\section{DAFTAR PUSTAKA}

\section{Buku}

Abul Qasim Abdul Karim Hawazin Al-Qusyairi An Naisaburi. Risalah Qusyairiyah Jakarta: Pustaka Anami.

Bagir, Haidar. belajar Hidup dari rumi. Jakarta Selatan: Mizan, 2015

Burhan, Bungin. Metodologi Penelitian Kualitatif. Depok: Rajagrafindo Pustaka 2015.

Eriyanto. Analisis isi: Pengantar Metodologi untuk Peneleitian Komunikasi dan Ilmu Sosial Lainnya.

Fatimah, Siti. Etika Persahabatan Remaja, (analisis isi pesan dalam novel tereliye. Semarang. 2018.

Ganjavi, Nizami. Layla Majnun Tanggerang Selatan: Javanica. 2020.

J, Lexy, Moleong. Metode Penelitian Kualitatif. Bandung: PT. Remaja Rosdakarya. 2004.

Khamis, Atiyah, M. "penyair wanita sufi rabiah" terjemahan. Aliudin mahjudin Jakarta: pustaka,1993

Krippendorff, Klaus. Analisis Isi Pengantar Teori dan Metodologi, Jakarta: Grafindo Persada. 1993.

Malik, Candra. Makrifat Cinta Jakarta Selatan: Noura Books.2012 
Rachmat, Kriyantono. Teknik Praktis Riset Komunikasi. Jakarta: Prenada Media Group. 2010.

Rumi, Jalaludin Matsnawi. Jakarta, penerbit zaman 2019

Setiawan, Bambang. Materi Pokok Metode Penelitian Komunikasi.

Simuh. Tasawuf dan Perkembangannya dalam Islam Jogjakarta: ircisod, 2019

Soehartono, Irawan. Metode Penelitian Sosial, Bandung: Remaja Rosdakarya. 2004.

\section{Akses daring}

Desta Leila Kartik, Hubungan intertekstual Cinta Abadi Layla Majnun dengan Romeo and Juliet, Http: Journal.unnes.ac.id/sju/index.php/jsi. diakses pada tanggal 18 oktober 2020 .

Novita Erma, Analisis Psikologi Sastra Tokoh Utama Novel maha Cinta Layla Majnun karya Syeikh Nizami. Http: media,neliti.com/media/publications.pdf. diakses pada tanggal 18 oktober 2020. 
240 | At- Tanzir: Jurnal Prodi Komunikasi dan Penyiaran Islam Vol. 11 No. 2, Desember 2020: 221-240 